\title{
Concentration of arsenic and heavy metals in snail tissues
}

\author{
Hava Mahmutovic ${ }^{1}$, Radmila Markovic², Jelena Janjic², Natasa Glamoclija², Branislav Baltic ${ }^{3}$, \\ Nenad Katanic ${ }^{4}$, Jelena Ciric *2
}

A b s t r a c t: The aim of this study was to determine arsenic and heavy metal concentrations (lead, mercury, copper, cadmium, zinc, iron and manganese) in snail tissues (foot and digestive gland) obtained from snail farms in Serbia (near urban areas). Snail samples were analysed using atomic absorption spectrophotometry. A total of 730 individual snail samples were included in this study. Snails were packed into plastic bags and transported to the laboratory at the Faculty of Veterinary Medicine, University of Belgrade. The levels of arsenic and mercury in the examined snail tissues were below the detection limit of the analytical method. Concentrations of heavy metals were higher in digestive gland tissues than in foot tissues.

Keywords: elements, foot, digestive gland, monitoring, environmental pollution.

\section{Introduction}

The city of Belgrade and the nearby region situated on two rivers (Sava and Danube) is one of the most economically developed regions in Serbia. Rivers play an important role in the economic and social development in this region. Rapid development of industrialisation and urbanisation in recent decades has resulted in significant negative impacts on ecosystems. Heavy metal concentrations have rapidly grown in the urban environments from these anthropogenic sources (Milanov et al., 2016; Janjic et al., 2015; Ivanovic et al., 2016; Jovanovic et al., 2017; Ciric et al., 2018). In spite of that, heavy metals are natural substances, so are also considered as environmental contaminants (Gawad, 2018). In general, they not degrade but accumulate throughout the trophic chain (Gupta and Singh, 2011). When the body accumulates heavy metals and does not metabolise them, they can be toxic (Gawad, 2018). Copper, manganese, zinc and iron are essential metals for many organisms. Cadmium and lead are non-essential metals, and their toxic effect can be relatively high in comparison to other metals (Zhiyou et al., 2016).

Land snails (Helix pomatia) accumulate heavy metals, and this property can be utilised for heavy metal monitoring in urban environments. Snails are a very suitable tool for diagnostics of regions contaminated with different heavy metals. Many studies (Beeby and Richmond, 2003; Notten et al., 2005; Dallinger et al., 2005; Nica et al., 2012) showed that land snails can accumulate high levels of copper, zinc, cadmium and lead in their foot and digestive gland tissues. The land snails have the potential to be used in environmental monitoring as model invertebrates for $\mathrm{Cu}, \mathrm{Zn}, \mathrm{Cd}$ and $\mathrm{Pb}$ accumulation in terrestrial ecosystems (Gomot-De Vaufleury, 2000).

Previous studies in Serbia showed accumulation of heavy metals in fish tissues from different locations (Jaric et al., 2011; Subotic et al., 2013; Janjic et al., 2015; Milanov et al., 2016; Ivanovic et al., 2016; Jovanovic et al., 2017). However, data on concentrations of different heavy metals in snail tissues are very limited in Serbia. This study investigated the concentration of arsenic and heavy metals (lead, mercury, copper, cadmium, zinc, iron and manganese) in snail tissues (foot and digestive gland) taken from snail farms in Serbia.

\section{Materials and methods}

Individuals of the adult land snail, Helix pomatia $(35.1 \pm 1.1 \mathrm{~mm}$ in shell diameter and $19.6 \pm 1.00$ $\mathrm{g}$ in body weight) were collected during 2017 from five different farms (F1, F2, F3, F4, F5) located near

\footnotetext{
${ }^{1}$ University of Tuzla, Faculty of Technology, Univerzitetska 8, 75000 Tuzla, Bosnia and Herzegovina;

2University of Belgrade, Faculty of Veterinary Medicine, Bulevar Oslobodjenja 18, 11000 Belgrade, Republic of Serbia;

${ }^{3}$ Institute of Meat Hygiene and Technology, Kacanskog 13, 11040 Belgrade, Republic of Serbia.

${ }^{4}$ Ministry of Agriculture, Forestry and Water Managament, Nemanjina 22-26, 11000 Belgrade, Republic of Serbia.
}

*Corresponding author: Jelena Ciric, 1310jecko@gmail.com 
Belgrade city, Serbia. F1, F2, F3 and F4 were located near traffic roads, and F5 was near the Danube River. Altogether, 730 individual snails were randomly collected (146 from each farm). Animals were packed into plastic bags and transported to the laboratory for heavy metal determinations, performed at the Faculty of Veterinary Medicine, University of Belgrade. The animals were washed with deionised water, steam treated (at $95-100^{\circ} \mathrm{C}$ for $5 \mathrm{~min}$ ), and the digestive glands and foot were rapidly dissected out. Half of the sample size of these tissues was used for heavy metal determination.

The concentrations of heavy metals were measured in the snail tissues. The digestive gland and foot samples were dried at $60^{\circ} \mathrm{C}$ for at least $48 \mathrm{~h}$ in Petri dishes. Half a gram of each dried sample was transferred into a $50 \mathrm{~mL}$ Erlenmeyer flask and 10 $\mathrm{mL}$ of concentrated nitric acid $\left(65 \% \mathrm{HNO}_{3}\right.$, Merck, Germany) was added. The flask was heated on an electric plate at low temperature until digestion was completed. When the digested solution became clear, the solution was evaporated to dryness. The sample was diluted with $10 \mathrm{~mL}$ of deionised water

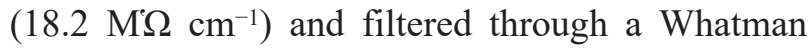
filter (Sigma-Aldrich, USA). Heavy metals were measured in triplicate by atomic absorption spectrophotometry (GBC 932 plus atomic absorption spectrometer, GBC Scientific Equipment, USA). All reagents and chemicals were of the highest purity grade available from Merck or Sigma-Aldrich, Germany.

The statistical analysis was performed using the GraphPad Prisma version 7.00 software. Means were compared for significance of differences by the Student's t-test at the probability of 0.05 . The samples were analysed in triplicate for each farm.

\section{Results and discussion}

Heavy metal concentrations in the different snail tissues (foot and digestive gland) of $\mathrm{H}$. pomatia collected at the five snail farms are given in Table 1. These elements were chosen due to their frequency in environmental pollution (due to urban area, industrial area, traffic road etc.). Also, previous studies have shown that land snails are capable

Table 1. Heavy metal concentrations $\left(\mu \mathrm{g} \mathrm{g}^{-1}\right)$ from snail (Helix pomatia) tissues from five different farms, $\mathrm{F} 1-\mathrm{F} 5(\mathrm{~N}=30$; mean \pm standard deviation)

\begin{tabular}{|c|c|c|c|c|c|}
\hline Heavy metal & F1 & F2 & F3 & F4 & F5 \\
\hline & Foot & & & & \\
\hline $\mathrm{Cd}$ & $0.19 \pm 0.01^{x}$ & $0.17 \pm 0.03^{x}$ & $0.22 \pm 0.02^{x}$ & $0.13 \pm 0.01^{x}$ & $0.11 \pm 0.02^{\mathrm{x}}$ \\
\hline $\mathrm{Hg}$ & & & BLD & & \\
\hline $\mathrm{Pb}$ & & & BLD & & \\
\hline As & & & BLD & & \\
\hline $\mathrm{Cu}$ & $12.46 \pm 1.86^{\mathrm{a}}$ & $26.58 \pm 3.67^{\mathrm{b}}$ & $21.60 \pm 3.52^{\mathrm{b}}$ & $9.74 \pm 1.44^{\text {ax }}$ & $21.01 \pm 3.91^{b x}$ \\
\hline $\mathrm{Zn}$ & $11.49 \pm 1.64^{x}$ & $12.83 \pm 1.58^{x}$ & $12.51 \pm 1.26^{x}$ & $12.11 \pm 1.12^{\mathrm{x}}$ & $13.09 \pm 1.65^{\mathrm{x}}$ \\
\hline $\mathrm{Fe}$ & $10.25 \pm 1.33^{\mathrm{ax}}$ & $12.30 \pm 2.50^{\mathrm{bx}}$ & $10.66 \pm 2.69^{\mathrm{ax}}$ & $9.77 \pm 0.62^{\mathrm{ax}}$ & $10.34 \pm 1.78^{\mathrm{ax}}$ \\
\hline \multirow[t]{2}{*}{$\mathrm{Mn}$} & $2.42 \pm 0.22^{\mathrm{ax}}$ & $1.69 \pm 0.11^{\mathrm{bx}}$ & $1.65 \pm 0.17^{\mathrm{bx}}$ & $2.05 \pm 0.19^{\mathrm{ax}}$ & $1.80 \pm 0.11^{\mathrm{bx}}$ \\
\hline & Digestive gland & & & & \\
\hline $\mathrm{Cd}$ & $0.66 \pm 0.03^{\text {ay }}$ & $1.14 \pm 0.10^{\text {by }}$ & $1.25 \pm 0.08^{\text {by }}$ & $0.90 \pm 0.02^{\text {ay }}$ & $0.92 \pm 0.08^{\text {ay }}$ \\
\hline $\mathrm{Hg}$ & & & BLD & & \\
\hline $\mathrm{Pb}$ & & & BLD & & \\
\hline As & & & BLD & & \\
\hline $\mathrm{Cu}$ & $11.68 \pm 0.65^{\mathrm{a}}$ & $26.62 \pm 1.97^{\mathrm{b}}$ & $23.33 \pm 1.64$ & $19.00 \pm 1.98^{y}$ & $11.41 \pm 1.01^{\text {ay }}$ \\
\hline $\mathrm{Zn}$ & $35.42 \pm 4.53^{y}$ & $67.23 \pm 5.90^{\text {ay }}$ & $46.06 \pm 3.15^{y}$ & $29.78 \pm 1.28^{\text {by }}$ & $30.49 \pm 2.92^{\text {by }}$ \\
\hline $\mathrm{Fe}$ & $77.66 \pm 8.57^{y}$ & $130.67 \pm 9.43^{\text {ay }}$ & $86.76 \pm 6.54^{y}$ & $49.18 \pm 3.84^{\text {by }}$ & $49.64 \pm 5.57^{\text {by }}$ \\
\hline Mn & $104.43 \pm 10.61^{y}$ & $296.08 \pm 39.68^{\text {ay }}$ & $172.99 \pm 10.75^{y}$ & $79.48 \pm 4.49^{\text {by }}$ & $76.65 \pm 7.92^{\text {by }}$ \\
\hline
\end{tabular}

Legend: BLD - below the limit of detection; Within a row, means with different lower-case superscript letters $(\mathrm{a}, \mathrm{b})$ differ significantly $(p<0.05)$; Within a column, means with different lower-case superscript letters $\left({ }^{x, y}\right)$ per heavy metal $(p<0.05)$ differ significantly. 
of accumulating high levels of different heavy metals (Beeby and Richmond, 2003; Notten et al., 2005; Dallinger et al., 2005; Nica et al., 2012). Cadmium concentrations in foot tissues ranged between $0.11 \pm 0.02 \mu \mathrm{g} \mathrm{g}^{-1}$ (F5) and $0.22 \pm 0.02 \mu \mathrm{g} \mathrm{g}^{-1}$ (F3). In digestive gland tissues, $\mathrm{Cd}$ concentrations ranged between $0.66 \pm 0.03 \mu \mathrm{g} \mathrm{g}^{-1}$ (F1) and $1.25 \pm 0.08 \mu \mathrm{g}$ $\mathrm{g}^{-1}(\mathrm{~F} 3)$. The farm location had a significant influence on heavy metal concentrations in the digestive gland tissues $(p<0.05)$. Similar, highly significant differences were found when comparing the higher $\mathrm{Cd}$ concentrations in snail digestive glands with the lower Cd concentrations in snail foot tissues (Table 1). Massadeh et al. (2016) showed that snail tissues are very good indicators for $\mathrm{Cd}$ accumulation. Similar results were presented in a study by Ciric et al. (2018). Our study suggests that variances in $\mathrm{Cd}$ level are indicative of environmental exposure differences between the farms (data not shown). The concentrations of $\mathrm{Mg}, \mathrm{Pb}$ and As were below the limit of detection in the examined snail tissues.

Copper concentrations in snail foot tissues ranged between $9.74 \pm 1.44 \mu \mathrm{g} \mathrm{g}^{-1}$ (F4) and $26.58 \pm 3.67 \mu \mathrm{g} \mathrm{g}^{-1}$ (F2) (Table 1). The highest $\mathrm{Cu}$ levels were measured in digestive gland tissues from F2, and foot tissue levels from this farm were similarly high. In fact, the $\mathrm{Cu}$ concentrations from F2 were significantly higher compared to F1 and F4 $(p<0.05)$ (Table 1). Also, significant differences in $\mathrm{Cu}$ levels were found between foot and digestive gland tissues from both F4 and F5. Copper is an essential element for snails (Yap and Noorhaidah, 2012). Similar results were presented in studies by Coeurdassier et al. (2007), Massadeh et al. (2016) and Ciric et al. (2018).

Zinc concentrations in snail foot tissues ranged between $11.49 \pm 1.64 \mu \mathrm{g} \quad \mathrm{g}^{-1}$ (F1) and $13.09 \pm 1.65 \mu \mathrm{g} \mathrm{g}^{-1}$ (F5). The concentration of $\mathrm{Zn}$ in foot tissues was significantly lower compared to digestive gland tissues, from all examined farms.
Nica et al. (2012) and Ciric et al. (2018) found the heavy metal concentration in different snail tissues depends on the farm and investigated snail tissue. These authors also showed that digestive gland tissues accumulated higher amounts of heavy metals compared to other snail tissues. Similar results were determined in our study.

Iron concentrations in snail foot tissues ranged between $9.77 \pm 0.62 \mu \mathrm{g} \mathrm{g}^{-1}$ (F4) and $12.30 \pm 2.50 \mu \mathrm{g} \mathrm{g}^{-1}$ (F2), and in snail digestive gland tissues were between $49.18 \pm 3.84 \mu \mathrm{g} \mathrm{g}^{-1}$ (F4) and $130.67 \pm 9.43 \mu \mathrm{g} \mathrm{g}^{-1}$ (F2). The results obtained show that Fe concentrations were significantly $(\mathrm{p}<0.05)$ higher in digestive gland tissues compared to foot tissues. Higher concentrations of $\mathrm{Fe}$ are probably due to an environmental pollution or other anthropogenic sources. According to Gomot and Pihan (1997), Gomot de Vaufleury and Pihan (2000) and Ciric et al. (2018), snails are target organisms that could be utilised for measuring environmental pollution with industrial waste.

Manganese concentrations in snail foot tissues ranged from $1.65 \pm 0.17 \mu \mathrm{g} \mathrm{g}^{-1}$ (F3) to $2.42 \pm 0.22 \mu \mathrm{g}$ $\mathrm{g}^{-1}(\mathrm{~F} 1)$. In snail digestive gland tissues, Mn concentrations ranged from $76.65 \pm 7.92 \mu \mathrm{g} \mathrm{g}^{-1}$ (F5) to $296.08 \pm 39.68 \mu \mathrm{g} \mathrm{g} \mathrm{g}^{-1}$ (F2). Significant differences were observed between tissues (foot and digestive gland tissues) and between the farms (Table 1). The levels of Mn reported in this study are similar to results of Sivaperumal et al. (2007) and Iwegbue et al. (2008).

\section{Conclusions}

Based on the present study, snails are a very good species for use in biomonitoring of various environmental pollutants. In particular, Helix pomatia accumulated high amounts of $\mathrm{Fe}$ and $\mathrm{Mn}$ (digestive gland tissues).

\title{
Koncentracija arsena i teških metala u tkivu puževa
}

\author{
Hava Mahmutović, Radmila Marković, Jelena Janjić, Nataša Glamočlija, Branislav Baltić, Nenad Katanić, \\ Jelena Ciric
}

A p s tra kt: Cilj ovog ispitivanja bio je utvrđivanje koncentracije arsena i teških metala (olova, žive, bakra, kadmijuma, cinka, gvožđa i mangana) u tkivima puževa (stopalo i digestivni trakt) poreklom sa odabranih farmi u Srbiji (u blizini urbanih područja). Uzorci puževa su analizirani pomoću atomskog apsorpcionog spektrofotometra. U ovu studiju uključeno je ukupno 730 pojedinačnih uzoraka puževa. Uzorci su upakovani u plastične kese, dopremljeni u laboratoriju Veterinarskog fakulteta, Univerziteta u Beogradu. Nivo arsena $i$ žive u ispitivanim uzorcima puževa bio su ispod granice detekcije analitičke metode. Koncentracija teških metala bila je veća u digestivnom tkivu u poređenju sa koncentracijom teških metala u stopalu puževa.

Ključne reči: elementi, stopala, digestivni trakt, monitoring, zagađenje životne sredine. 
Disclosure Statement: No potential conflict of interest was reported by the authors.

Acknowledgment: This paper was supported by the Ministry of Education, Science and Technological Development of the Republic of Serbia, Project "Selected biological hazards to the safety/quality of food of animal origin and the control measures from farm to consumer" (31034).

\section{References}

Beeby, A. \& Richmond, L. (2003). Do the soft tissues of Helix aspersa serve as a quantitative sentinel of predicted free lead concentrations in soils? Applied Soil Ecology, $22(2), 159-165$.

Borgo, R., Souty-grosset, C. \& Gomot, L. (1995). Etud e d e l'AD N mitochondria 1 d'espece s d'escar - got s du genr e Helix par PCR-RFLP. Comptes Rendiis de la Socitte de Biologic, 189, 629-636.

Ciric, J., Ceric, O., Markovic, R., Janjic, J., Spiric, D., Popovic, M., Pecanac, B., Baltic, B. \& Baltic, Z. M. (2018). Seasonal distributions of heavy metal concentrations in different snail (Helix pomatia) tissues from an urban environment in Serbia. Environmental Science and Pollution Research. DOI: 10.1007/s11356-018-3295-1

Coeurdassier, M., Scheifler, R., De Vaufleury, A., Crini, N., Saccomani, C., Du Mont, L. S. \& Badot, P. M. (2007). Earthworms influence metal transfer from soil to snails. Applied Soil Ecology, 35 (2), 302-310.

Dallinger, R. \& Wieser, W. (1984). Patterns of accumulation, distribution and liberation of $\mathrm{Zn}, \mathrm{Cu}, \mathrm{Cd}$ and $\mathrm{Pb}$ in different organs of the land snail Helix pomatia L. Comparative Biochemistry and Physiology part C: Comparative Pharmacology, 79 (1), 117-124.

Dallinger, R., Chabicovsky, M., Hodl, E., Prem, C., Hunziker, P., Manzl, C. (2005). Copper in Helix pomatia (Gastropoda) is regulated by one single cell type: differently responsive metal pools in rhogocytes. American Journal of Physiology - Regulatory, Integrative and Comparative Physiology, 289 (4), 1185-1195.

Gawad, S. S. A. (2018). Acute toxicity of some heavy metals to the fresh water snail, Theodoxus niloticus (Reeve, 1856). The Egyptian Journal of Aquatic Research, 44 (2), 83-87.

Gomot de Vaufleury, A. \& Pihan, F. (2000). Growing snails used as sentinels to evaluate terrestrial environment contamination by trace element. Chemosphere, 40, 275-284.

Gomot, A. \& Pihan, F. (1997). Comparison of the bioaccumulation capacities of copper and zinc in two snail subspecies (Helix). Ecotoxicology and Environmental Safety, 38 (2), 85-94.

Gomot-De Vaufleury, A. (2000). Standardized growth toxicity testing $(\mathrm{Cu}, \mathrm{Zn}, \mathrm{Pb}$, and Pentachlorophenol) with $\mathrm{He}$ lix aspersa. Ecotoxicology and Environmental Safety, 46 (1), 41-50.

Greville, R. W. \& Morgan, A. J. (1989). Concentrations of metals $(\mathrm{Cu}, \mathrm{Pb}, \mathrm{Cd}, \mathrm{Zn}, \mathrm{Ca})$ in six species of British terrestrial gastropods near a disused lead and zinc mine. Journal of Molluscan Studies, 55 (1), 31-36.
Gupta, S. K. \& Singh, J., (2011). Evaluation of Mollusca as sensitive indicator of heavy metal pollution in aquatic system: a review. Special Issue. Environmental Management and Sustainable Development, 2 (1), 49-57.

Ivanovic, J., Janjic, J., Baltic, M., Milanov, R., Boskovic, M., Markovic, R.V. \& Glamoclija, N. (2016). Metal concentrations in water, sediment and three fish species from the Danube River, Serbia: a cause for environmental concern. Environmental Science and Pollution Research, 23 (17), 17105-17112.

Iwegbue, C. M., Arimoro, F. O., Nwajei, G. E. \& Eguavoen, O. (2008). Heavy metal content in the African giant snail Archachatina marginata (Swainson, 1821) (Gastropoda: pulmonata: achatinidae) in Southern Nigeria. Folia Malacologica, 16 (1), 31-34.

Janjic, J., Ivanovic, J., Markovic, R., Starcevic, M., Boskovic, M., Djordjevic, V. \& Baltic, M. Z. (2015). Metal concentration in muscle tissue of carp and pike from different fish ponds in Belgrade area. Journal of Agricultural Science and Technology, 5, 429-436.

Jaric, I., Visnjic-Jeftic, Z., Cvijanovic, G., Gacic, Z., Jovanovic, L., Skoric, S. \& Lenhardt, M. (2011). Determination of differential heavy metal and trace element accumulation in liver, gills, intestine and muscle of sterlet (Acipenser ruthenus) from the Danube River in Serbia by ICP-OES. Microchemical Journal, 98 (1), 77-81.

Jovanovic, D. A., Markovic, R. V., Teodorovic, V. B., Sefer, D. S., Krstic, M. P., Radulovic, S. B. \& Baltic, M. Z. (2017). Determination of heavy metals in muscle tissue of six fish species with different feeding habits from the Danube River, Belgrade - public health and environmental risk assessment. Environmental Science and Pollution Research, 24 (12), 11383-11391.

Laskowski, R. \& Hopkin, S. P. (1996). Effect of $\mathrm{Zn}, \mathrm{Cu}, \mathrm{Pb}$, and Cd on fitness in snails (Helix aspersa), Ecotoxicology and Environmental Safety, 34 (1), 59-69.

Massadeh, A. M., Alomary, A. A., Mir, S., Momani, F. A., Haddad, H. I. \& Hadad, Y. A. (2016). Analysis of Zn, $\mathrm{Cd}, \mathrm{As}, \mathrm{Cu}, \mathrm{Pb}$, and $\mathrm{Fe}$ in snails as bioindicators and soil samples near traffic road by ICP-OES. Environmental Science and Pollution Research, 23 (13), 13424-13431.

Milanov, Dj. R., Krstic, P. M., Markovic, V. R., Jovanovic, A. D., Baltic, M. B., Ivanovic. S. J. \& Baltic, Z. M. (2016). Analysis of heavy metals concentration in tissues of three different fish species included in human diet from Danube River. Acta Veterinaria - Beograd, 66 (1), 89-102. 
Nica, D. V., Bura, M., Gergen, I., Harmanescu, M. \& Bordean, D. M. (2012). Bioaccumulative and conchological assessment of heavy metal transfer in a soil-plant-snail food chain. Chemistry Central Journal, 6 (1), 55.

Notten, M. J. M., Oosthoek, A. J. P., Rozema, J. \& Aerts, R. (2005). Heavy metal concentrations in a soil-plant-snail food chain along a terrestrial soil pollution gradient. Environmental Pollution, 138 (1), 178-190.

Sivaperumal, P., Sankar, T. V. \& Nair, P. V. (2007). Heavy metal concentrations in fish, shellfish and fish products from internal markets of India vis-a-vis international standards. Food Chemistry, 102 (3), 612-620.

Subotic, S., Spasic, S., Visnjic-Jeftic, Z., Hegedis, A., Krpo-Cetkovic, J., Mickovic, B. \& Lenhardt, M. (2013). Heavy metal and trace element bioaccumulation in target tissues of four edible fish species from the Danube River (Serbia). Ecotoxicology and Environmental Safety, 98, 196-202.

Yap, C. K. \& Noorhaidah, A. (2012). Distribution of heavy metal concentrations in the different soft and hard tissues of tropical mud-flat snail Telescopium telescopium (family: Potamididae) collected from Sepang Besar River. Pertanika Journal of Tropical Agricultural Science, 35 (3), 427-437.

Zhiyou, F. U., Fengchang, W. U., Chen, Lulu, Bingbing, X. U., Feng, Chenglian, Bai, Yingchen, Liao, Haiqing, Sun, Siyang, Giesy, John P. \& Guo, Wenjing. (2016). Copper and zinc, but not other priority toxic metals, pose risks to native aquatic species in a large urban lake in Eastern China. Environmental Pollution, 219, 1069-1076.

Paper received: 2.10 .2018 .

Paper corrected: 14.11.2018.

Paper accepted: 22.11.2018. 